\title{
Development and Statistical Optimisation of Buspirone Hydrochloride Buccoadhesive Films
}

\author{
Upendra Nagaich, ${ }^{1}$ Vandana Chaudhary, ${ }^{2}$ and Jaya Nagaich ${ }^{3}$ \\ ${ }^{1}$ Department of Pharmaceutics, Amity Institute of Pharmacy, Amity University, Noida, Uttar Pradesh 201313, India \\ ${ }^{2}$ Department of Pharmaceutics, B. S. Anangpuria Institute of Pharmacy, Faridabad, India \\ ${ }^{3}$ Department of Pharmaceutics, Kota College of Pharmacy, Kota, India
}

Correspondence should be addressed to Upendra Nagaich; upendra_nagaich@hotmail.com

Received 27 May 2014; Accepted 16 September 2014; Published 30 October 2014

Academic Editor: Anuradha Mishra

Copyright (C) 2014 Upendra Nagaich et al. This is an open access article distributed under the Creative Commons Attribution License, which permits unrestricted use, distribution, and reproduction in any medium, provided the original work is properly cited.

\begin{abstract}
The aim of the present study was to prepare unidirectional buccal films of buspirone hydrochloride by solvent casting technique. Hydroxypropylmethylcellulose (HPMC K15M) and Eudragit RL-100 were used as polymers in different proportion. Polyethylene glycol 400 and sodium lauryl sulphate were used as plasticizer and permeation enhancer, respectively, in different concentration. In the formulation, total amount of polymer $\left(X_{1}\right)$ and percentage of HPMC K15M $\left(X_{2}\right)$ were kept as independent variables. Afterwards, statistically optimized process was carried out and two optimized formulations (OF1 and OF2) were developed. The observed results of optimized formulation were showed a greater degree of percentage of similarity with predicted values. The stability studies showed that there was no significant change found in physicochemical properties, in-vitro release, and ex-vivo diffusion studies.
\end{abstract}

\section{Introduction}

The present paper deals with the planning and realization of mucoadhesive polymeric films containing an anxiolytic drug buspirone hydrochloride for the buccal administration in the oral cavity. The advantage resides on the reduction of dose of the drug and hepatic first pass metabolism because of its localization in the oral cavity for systemic release. One particular problem that is common to many drug delivery systems, aimed at the treatment of the oral cavity diseases, is the short residence time at the site of application. This problem may be resolved by using bioadhesive polymers, that is, polymers that exhibit characteristic adhesive interactions with biological membranes [1]. Various bioadhesive mucosal dosage forms including adhesive tablets, gels, and films have been developed [2]. However, buccal films are preferable over adhesive tablets in terms of flexibility and comfort. In addition, they can circumvent the relatively short residence time of oral gels on the mucosa, which are easily washed and removed by saliva. Moreover, buccal films are also suitable for protecting wound surfaces, thus reducing pain and increasing the treatment effectiveness [3]. In this study, mucoadhesive films were developed by using the solvent casting method. For this purpose, hydrophilic water-soluble film forming polymer HPMC K15M and hydrophobic water permeable polymer (Eudragit RL-100) for controlling rate of release of drug; thus, diffusion of drug was used. Polyethylene glycol (PEG) 400 was used as plasticizer and sodium lauryl sulphate was used as permeation enhancer in varying concentration. In order to prepare the films, film-forming polymers were initially used alone and successively in combination with water permeable polymer (Eudragit RL-100) for controlling the rate of drug release [4]. The films with the best results were selected on the basis of their in-vitro, ex-vivo and optimisation of various parameters like $T_{50 \%}$ and $T_{80 \%}$; diffusion at $3 \mathrm{~h}, 6 \mathrm{~h}$, and $9 \mathrm{~h}$ were carried out. Buspirone hydrochloride was eventually introduced in the film; hence, formulations OF1 and OF2 closely met desired data and were able to diffuse continuously the drug for $12 \mathrm{~h}$, which can maintain the desired therapeutic concentration in plasma. 


\section{Materials and Methods}

2.1. Materials. Buspirone Hydrochloride was purchased from Sigma chemicals, Bangalore (India). HPMC K15M was received as gift sample from Central drug house (P) Ltd., Delhi, India, and Eudragit RL-100 also received as gift sample from Sun pharmaceuticals, Baroda, India. Polyethylene glycol (PEG 400) and sodium lauryl sulphate were received from Merck Ltd., Mumbai (India). The polymers were dissolved in solvent mixture of distilled water and alcohol.

\subsection{Methods}

\subsubsection{Preformulation Studies}

Solubility Studies. Solubility may be defined as spontaneous interaction of two or more substances to form homogeneous dispersions. The solubility of buspirone hydrochloride was studied in various aqueous and nonaqueous solvents. $10 \mathrm{mg}$ of drug was taken in $10 \mathrm{~mL}$ of each solvent at room temperature, in screw-capped test tubes and shaken for $24 \mathrm{~h}$ in wrist action shaker. The solubility was checked by UV spectroscopy at $254 \mathrm{~nm}$ [5].

Partition Coefficient. The partition coefficient directly influences the permeability through various membranes. The study has been designed to determine partition coefficient of drug in 1-octanol: phosphate buffer saline (PBS) pH 6.8 [6].

Partition Coefficient between 1 Octanol: PBS ( $p H$ 6.8) Was Determined by the Following Method. Equal volume $(10 \mathrm{~mL})$ of PBS ( $\mathrm{pH}$ 6.8) and 1-octanol was added to $10 \mathrm{mg}$ of accurately weighed drug buspirone hydrochloride in glassstoppered tube. The mixture was shaken for $24 \mathrm{~h}$ on a wrist action shaker. The drug concentration in both aqueous and 1-octanol phases was determined spectrophotometrically at $250 \mathrm{~nm}$ after separating both phases and calculating the partition coefficient [6].

Experimental Design Approach. Experimental design is a statistical design that prescribes or advises a set of combination of variables. The number and layout of these design points within the experimental region depend on the number of the effects that must be estimated. Depending on the number of factors their levels, possible interactions, and order of the model, various experimental designs are chosen. Each experiment can be represented as a point within the experimental domain, the point being defined by its coordinate (the value given to the variables) in the space.

It is a $3^{2}$ full factorial experimental design, which uses dimensional factor space at the corner of the design space. A factorial design was used in experiment, the effects of different factors, or conditions on experimental results were elucidated. These were the design points for simultaneous determination of the effect of several factors and their interaction.

Where the three factors was considered, at two levels, nine experiments were necessary which are situated at the corners of an orthogonal cube in a three dimensional space. The numbers of experiments are given by $2^{n}$, where $n$ is the
TABLE 1: Independent variables and their levels.

\begin{tabular}{lccc}
\hline Variables (code) & \multicolumn{3}{c}{ Level } \\
& -1 & 0 & 1 \\
\hline Total amount of polymer (mg) $X_{1}$ & 15 & 30 & 45 \\
Percentage of HPMC K15M (\%) $X_{2}$ & 66.66 & 80 & 100 \\
\hline
\end{tabular}

number of factors. If the numbers of factors and levels are large, then the number of experiments needed to complete a factorial design is large.

The fitting of an empirical polynomial equation to the experimental result facilitates the optimisation procedures. The general polynomial equation is as follows:

$$
\begin{aligned}
Y= & B_{0}+B_{1} X_{1}+B_{2} X_{2}+B_{3} X_{3}+\cdots+B_{12} X_{1} X_{2}+B_{13} X_{1} X_{3} \\
& +B_{23} X_{2} X_{3}+\cdots+B_{123} X_{1} X_{2} X_{3},
\end{aligned}
$$

where $Y$ is the response (dependent variable) as shown in Table 1.

$X_{1}, X_{2}, X_{3}$ were the independent variable (concentration) of the 1,2 , and 3 factors [7]: $B_{1}, B_{2}, B_{3}, B_{12}, B_{13}, B_{23}, B_{123}$ is the polynomial coefficients. $B_{0}$ is the intercept (which represents the response when the levels of all factors are low). Generation and evaluation of the statistical experimental design were performed with the Microsoft Excel 2002 AddIn, Essential Regression. The studied factors were of total weight of polymer, and percentage of HPMC K15M in the formulations, as these polymers and the level settings used were found to have a significant effect on mucoadhesion and drug release of the matrices in preliminary investigations. The response variables were optimize the maximum detachment force (MDF). A design matrix was comprising of nine experimental runs. Table 1 summarizes the factors and their levels.

Buccal films were prepared by solvent casting technique. HPMC K15M was used as a rate controlling polymer and Eudragit RL-100 was used as a film forming agent, in the preparation of films. Polyethylene glycol (PEG 400) was used as a plasticizer. Sodium lauryl sulphate was used as permeation enhancer. The polymers were dissolved in solvent mixture of water and alcohol. The drug was then dispersed uniformly in the viscous solution with continuous stirring. The resulting mass was poured onto the glass mould of $2 \mathrm{~cm}$ in diameter. The moulds were left undisturbed at room temperature for a day. The films could be retrieved intact by slowly lifting from the moulds. The composition of films was shown in Table 2, based on $3^{2}$ full factorial designs [8].

Ethyl cellulose $10 \% \mathrm{w} / \mathrm{v}$ was dissolved in ethanol and polyethylene glycol (PEG 400) as a plasticizer was added to formulate backing layer by casting $0.5 \mathrm{~mL}$ of the solution on the dry films [9].

2.2.2. Evaluation Parameters. Physicochemical evaluations of buspirone hydrochloride films as shown in Table 3.

2.2.3. Surface $p H$. The surface $\mathrm{pH}$ was determined by the method similar to that used by Ilango et al. [9]. A combined 
TABLE 2: $3^{2}$ full factorial design for the formulation of bucco-adhesive films of Buspirone Hydrochloride.

\begin{tabular}{|c|c|c|c|c|c|c|c|c|c|c|c|c|}
\hline \multirow{3}{*}{$\begin{array}{l}\text { Formulation } \\
\text { code }\end{array}$} & \multirow{3}{*}{$\begin{array}{l}\begin{array}{c}\text { Amount of } \\
\text { drug }\end{array} \\
\text { In mg } \\
\end{array}$} & \multirow{3}{*}{$\begin{array}{c}\text { Total amount } \\
\text { of polymer } \\
X_{1}\end{array}$} & \multirow{2}{*}{\multicolumn{2}{|c|}{$\begin{array}{c}\text { Amount of } \\
\text { HPMC K15M } \\
X_{2}\end{array}$}} & \multirow{2}{*}{\multicolumn{2}{|c|}{$\begin{array}{c}\text { Amount of } \\
\text { Eudragit RL-100 }\end{array}$}} & \multirow{2}{*}{\multicolumn{2}{|c|}{$\begin{array}{l}\text { Amount of } \\
\text { permeation } \\
\text { enhancer }\end{array}$}} & \multirow{2}{*}{\multicolumn{2}{|c|}{$\begin{array}{c}\begin{array}{c}\text { Amount of } \\
\text { plasticizer }\end{array} \\
\text { PEG } 400\end{array}$}} & \multicolumn{2}{|c|}{ Solvents } \\
\hline & & & & & & & & & & & \multirow{2}{*}{$\begin{array}{l}\text { Water } \\
\text { In } \mathrm{mL}\end{array}$} & \multirow{2}{*}{$\begin{array}{l}\text { Alcohol } \\
\text { In mL } \\
\end{array}$} \\
\hline & & & In $\%$ & In $\mathrm{mg}$ & In $\%$ & In mg & In $\%$ & In $\mathrm{mL}$ & In $\%$ & In $\mathrm{mL}$ & & \\
\hline $\mathrm{F} 1$ & 50 & 150 & 100 & 150 & 0 & 0 & 5 & 0.009 & 20 & 0.03 & 15 & 0 \\
\hline F2 & 50 & 300 & 100 & 300 & 0 & 0 & 5 & 0.018 & 20 & 0.06 & 30 & 0 \\
\hline F3 & 50 & 450 & 100 & 450 & 0 & 0 & 5 & 0.027 & 20 & 0.09 & 45 & 0 \\
\hline F4 & 50 & 150 & 80 & 120 & 20 & 30 & 5 & 0.009 & 20 & 0.03 & 12 & 7.5 \\
\hline F5 & 50 & 300 & 80 & 240 & 20 & 60 & 5 & 0.018 & 20 & 0.06 & 24 & 15 \\
\hline F6 & 50 & 450 & 80 & 360 & 20 & 90 & 5 & 0.027 & 20 & 0.09 & 36 & 27.5 \\
\hline F7 & 50 & 150 & 66.66 & 100 & 33.33 & 50 & 5 & 0.009 & 20 & 0.03 & 10 & 12.5 \\
\hline F8 & 50 & 300 & 66.66 & 200 & 33.33 & 100 & 5 & 0.018 & 20 & 0.06 & 20 & 25 \\
\hline F9 & 50 & 450 & 66.66 & 300 & 33.33 & 150 & 5 & 0.027 & 20 & 0.09 & 30 & 37.5 \\
\hline
\end{tabular}

TABLE 3: Physicochemical parameters of various formulations of buccal films.

\begin{tabular}{|c|c|c|c|c|c|c|c|}
\hline $\begin{array}{l}\text { Formulation } \\
\text { code }\end{array}$ & Surface $\mathrm{pH}^{*}$ & Swelling studies & $\begin{array}{l}\text { Weight uniformity } \\
(\mathrm{mg})^{*}\end{array}$ & $\begin{array}{c}\text { Thickness } \\
(\mu \mathrm{m})^{*}\end{array}$ & $\begin{array}{c}\text { Folding } \\
\text { endurance* }\end{array}$ & Drug content ${ }^{*}$ & $\begin{array}{l}\text { Bioadhesion } \\
\text { strength* }^{*}(\mathrm{~g})\end{array}$ \\
\hline F1 & $6.3 \pm 0.02$ & 1.22 & $155.2 \pm 3.56$ & $124.74 \pm 1.5$ & $29 \pm 4$ & $98.12 \pm 1.26$ & $8.87 \pm 0.12$ \\
\hline $\mathrm{F} 2$ & $6.6 \pm 0.04$ & 1.37 & $303.1 \pm 4.78$ & $211.48 \pm 2.2$ & $46 \pm 3$ & $98.17 \pm 0.96$ & $10.19 \pm 0.34$ \\
\hline F3 & $6.7 \pm 0.03$ & 1.59 & $456.1 \pm 6.13$ & $314.22 \pm 2.6$ & $68 \pm 4$ & $99.07 \pm 0.65$ & $13.67 \pm 0.49$ \\
\hline $\mathrm{F} 4$ & $6.3 \pm 0.04$ & 1.09 & $153.2 \pm 1.92$ & $104.94 \pm 0.8$ & $21 \pm 4$ & $98.34 \pm 1.37$ & $7.38 \pm 0.53$ \\
\hline F5 & $6.6 \pm 0.02$ & 1.25 & $292.7 \pm 3.87$ & $202.88 \pm 1.6$ & $34 \pm 4$ & $98.67 \pm 1.16$ & $9.61 \pm 0.48$ \\
\hline F6 & $6.3 \pm 0.03$ & 1.41 & $441.2 \pm 4.27$ & $309.82 \pm 1.8$ & $53 \pm 5$ & $98.47 \pm 1.27$ & $11.39 \pm 0.65$ \\
\hline F7 & $6.6 \pm 0.04$ & 1.01 & $146.1 \pm 1.69$ & $91.74 \pm 0.7$ & $19 \pm 3$ & $98.05 \pm 1.22$ & $6.93 \pm 0.81$ \\
\hline F8 & $6.7 \pm 0.05$ & 1.12 & $305.3 \pm 2.45$ & $193.48 \pm 1.3$ & $31 \pm 5$ & $98.21 \pm 1.34$ & $8.08 \pm 0.69$ \\
\hline F9 & $6.5 \pm 0.02$ & 1.27 & $447.1 \pm 4.43$ & $295.22 \pm 1.9$ & $41 \pm 5$ & $98.19 \pm 1.26$ & $9.23 \pm 0.78$ \\
\hline
\end{tabular}

${ }^{*}$ Data represents mean $\pm \mathrm{SD}, n=3$.

glass electrode was used for this purpose. The films were kept in contact with $0.5 \mathrm{~mL}$ of distilled water for $1 \mathrm{~h}$. $\mathrm{pH}$ was noted by bringing the electrode near the surface of the formulations and allowing it to equilibrate for $1 \mathrm{~min}$ [9].

2.2.4. Swelling Study. Three films of $2 \mathrm{~cm}^{2}$ of each formulation of different batches were accurately weighed $\left(W_{1}\right)$ and it was placed in petridish containing $25 \mathrm{~mL}$ distilled water. Films were carefully removed from the petridish after $10 \mathrm{~min}$. and wiped by using tissue paper. The weight of the swollen film was noted $\left(W_{2}\right)$. The swelling index was calculated by the formula [9].

$$
\text { Swelling index }=\frac{\left(W_{2}-W_{1}\right)}{W_{1}},
$$

where $W_{1}=$ dry weight of the film and $W_{2}=$ wet weight of the film.

2.2.5. Weight Uniformity. Three samples of films from each batch were randomly taken and weighed individually each film. The data were analyzed for mean weight and standard deviation [9].
2.2.6. Film Thickness. Five samples from each batch were taken and thickness of each film was determined using "screw gauge." The data were analyzed for mean film thickness and standard deviation, number of times repetition $(n)=5$, detection limit: $0.05 \mathrm{~mm}$ [9].

2.2.7. Folding Endurance. Folding endurance of the film was determined by repeatedly folding a small strip of film at the same place until it broke. The number of times the film could be folded at the same place without breaking gave the value of folding endurance [9].

\subsubsection{Evaluation of Buccal Films of Buspirone Hydrochloride}

Test for Drug Content Uniformity of Active Ingredient. A $2 \mathrm{~cm}^{2}$ film was cut into small pieces, dissolved into $10 \mathrm{~mL}$ of methanol and diluted into $100 \mathrm{~mL}$ with the simulated salivary fluid at $\mathrm{pH}$ 6.8, and shaken continuously. The solution was then filtered and drug was estimated spectrophotometrically at $254 \mathrm{~nm}$ after dilution [10].

In-Vitro Bioadhesive Studies. The bioadhesive strength of the buccoadhesive patch with porcine mucosa was measured 
TABLE 4: Diffusion kinetic profile of various formulations.

\begin{tabular}{|c|c|c|c|c|c|c|c|c|c|}
\hline \multirow{2}{*}{$\begin{array}{l}\text { Kinetic profile of } \\
\text { formulations }\end{array}$} & \multicolumn{2}{|c|}{ For Higuchi equation } & \multicolumn{2}{|c|}{$\begin{array}{c}\text { For Peppas } \\
\text { Korsmayer equation }\end{array}$} & \multicolumn{3}{|c|}{ For 1st order equation } & \multicolumn{2}{|c|}{ For zero order equation } \\
\hline & $N$ & $R^{2}$ & $N$ & $\log K$ & $N$ & $R^{2}$ & $K$ & $K$ & $R^{2}$ \\
\hline Desirability & 25.130 & 0.912 & 0.698 & 1.218 & -0.108 & 0.750 & -0.249 & 8.926 & 0.961 \\
\hline $\mathrm{F} 1$ & 44.862 & 0.801 & 0.230 & 1.794 & -0.214 & 0.907 & -0.492 & 15.27 & 0.039 \\
\hline $\mathrm{F} 2$ & 30.364 & 0.900 & 0.369 & 1.595 & -0.129 & 0.883 & -0.298 & 9.98 & 0.467 \\
\hline F3 & 28.391 & 0.988 & 0.462 & 1.487 & -0.102 & 0.955 & -0.235 & 9.450 & 0.676 \\
\hline $\mathrm{F} 4$ & 32.988 & 0.799 & 0.319 & 1.661 & -0.134 & 0.979 & -0.308 & 10.41 & 0.299 \\
\hline F5 & 26.614 & 0.975 & 0.417 & 1.494 & -0.082 & 0.968 & -0.188 & 8.856 & 0.659 \\
\hline F6 & 24.497 & 0.994 & 0.549 & 1.347 & -0.069 & 0.984 & -0.160 & 8.255 & 0.818 \\
\hline F7 & 30.028 & 0.970 & 0.456 & 1.518 & -0.131 & 0.903 & -0.301 & 9.958 & 0.626 \\
\hline F8 & 24.480 & 0.992 & 0.459 & 1.422 & -0.067 & 0.975 & -0.154 & 8.185 & 0.728 \\
\hline F9 & 22.350 & 0.985 & 0.603 & 1.261 & -0.057 & 0.983 & -0.132 & 7.558 & 0.849 \\
\hline
\end{tabular}

$N$ : release exponent, $R$ : correlation coefficient, $\log K$ : slope.

TABLE 5: Formulation chart for optimized formulation.

\begin{tabular}{|c|c|c|c|c|c|c|c|c|c|c|c|c|}
\hline \multirow{3}{*}{$\begin{array}{l}\text { Formulation } \\
\text { code }\end{array}$} & \multirow{3}{*}{$\begin{array}{l}\text { Amount of } \\
\text { drug }(\mathrm{mg})\end{array}$} & \multirow{3}{*}{$\begin{array}{l}\text { Total amount } \\
\text { of polymer } X_{1}\end{array}$} & \multirow{2}{*}{\multicolumn{2}{|c|}{$\begin{array}{c}\text { Amount of } \\
\text { HPMC K15M } \\
X_{2}\end{array}$}} & \multirow{2}{*}{\multicolumn{2}{|c|}{$\begin{array}{l}\text { Amount of } \\
\text { Eudragit RL-100 }\end{array}$}} & \multirow{2}{*}{\multicolumn{2}{|c|}{$\begin{array}{l}\text { Amount of } \\
\text { permeation } \\
\text { enhancer } \\
\text { Na-lauryl sulphate }\end{array}$}} & \multirow{2}{*}{\multicolumn{2}{|c|}{$\begin{array}{l}\text { Amount of } \\
\text { plasticizer } \\
\text { PEG } 400\end{array}$}} & \multicolumn{2}{|c|}{ Solvent } \\
\hline & & & & & & & & & & & Water & Alcohol \\
\hline & & & (\%) & (mg) & (\%) & (mg) & (\%) & $(\mathrm{mL})$ & (\%) & $(\mathrm{mL})$ & $(\mathrm{mL})$ & $(\mathrm{mL})$ \\
\hline OF1 & 50 & 400 & 75 & 300 & 25 & 100 & 5 & 0.024 & 20 & 0.08 & 30 & 20 \\
\hline OF2 & 50 & 350 & 70 & 245 & 30 & 105 & 5 & 0.021 & 20 & 0.07 & 24.5 & 17.5 \\
\hline
\end{tabular}

using modified two arm balance. One arm of the balance was replaced with a steel pan. Pig buccal mucosa was obtained from local slaughter house and stored in simulated saliva fluid of $\mathrm{pH} 6.8$ at $4^{\circ} \mathrm{C}$. The experiment was performed within three hours of procurement of the mucosa. The buccal mucosa was fixed at the bottom of a glass beaker of capacity $100 \mathrm{~mL}$ with cyanoacrylate adhesive and this assembly was put in a beaker of capacity $500 \mathrm{~mL}$. Simulated saliva was added into the $500 \mathrm{~mL}$ beaker until the upper surface of buccal mucosa completely dipped in the simulated saliva fluid to maintain the viability of buccal mucosa during the experiment. The patch was attached to the steel pan of the apparatus, the beaker was raised slowly until contact between buccal mucosa, and patch was established. A preload of $20 \mathrm{gm}$ was placed on clamp for $5 \mathrm{~min}$ (preload time) to establish adhesion bonding between patch and buccal mucosa. The preload and preload time were kept constant for all the formulations. After completion of preload time, preload was removed from clamp, and water was then added into the beaker from the burette [10].

The addition of water was stopped when patch just detached from buccal mucosa. The weight of water required to detach the patch from buccal mucosa was noted. This was taken as a measure of mucoadhesive strength. The experiment was repeated with fresh mucosa in an identical manner for all the patches. Bioadhesion force $\left(\mathrm{kg} \mathrm{m}^{-1} \mathrm{~s}^{2}\right)$ is given by following equation:

$$
F=\frac{\left(W_{w} \times g\right)}{A},
$$

where $F$ is the bioadhesion force $\left(\mathrm{kg} \mathrm{m}^{-1} \mathrm{~s}^{2}\right), W_{w}$ is the weight of water added, $g$ is the acceleration due to gravity $\left(\mathrm{cm} / \mathrm{s}^{2}\right)$, and $A$ is the surface area of the patch $\left(\mathrm{cm}^{2}\right)$.

In-Vitro Release Studies by Using Dissolution Apparatus. The drug release was determined using U.S.P. dissolution test apparatus, thermostated at $37 \pm 2^{\circ} \mathrm{C}$, and stirred at a rate of $50 \mathrm{rpm}$. Sink condition was maintained throughout the study. Each film was fixed on glass slide with the help of cyanoacrylate adhesive, so that the drug could be released only from upper face. The slide was immersed in the vessel containing $250 \mathrm{~mL}$ of simulated salivary fluid $\mathrm{pH}$ 6.8. Aliquots of $5 \mathrm{~mL}$ of sample were withdrawn with graduated pipette at every $1 \mathrm{~h}$ time intervals up to $9 \mathrm{~h}$ with equal volume of simulated salivary fluid [11].

The samples were diluted with simulated salivary fluid and analyzed spectrophotometrically at $254 \mathrm{~nm}$ and the 
TABle 6: Physicochemical parameters of optimized formulations.

\begin{tabular}{lccccccc}
\hline Formulations & Surface $\mathrm{pH}^{*}$ & Swelling studies & $\begin{array}{c}\text { Weight uniformity } \\
(\mathrm{mg})^{*}\end{array}$ & $\begin{array}{c}\text { Thickness } \\
(\mu \mathrm{m})^{*}\end{array}$ & $\begin{array}{c}\text { Folding } \\
\text { endurance }^{*}\end{array}$ & $\begin{array}{c}\text { Drug content }^{*} \\
\text { strength }^{*}(\mathrm{~g})\end{array}$ \\
\hline OF1 & $6.2 \pm 0.03$ & 1.21 & $413.21 \pm 2.66$ & $292.52 \pm 1.65$ & $144 \pm 3$ & $98.42 \pm 1.36$ & $9.93 \pm 0.34$ \\
OF2 & $6.4 \pm 0.04$ & 1.17 & $353.47 \pm 3.48$ & $259.69 \pm 2.23$ & $138 \pm 4$ & $98.07 \pm 0.86$ & $9.21 \pm 0.58$ \\
\hline
\end{tabular}

${ }^{*}$ Data represents mean $\pm \mathrm{SD}, n=3$.

cumulative amount of drug released at various time intervals was calculated. The test was carried out in triplicate.

Ex-Vivo Diffusion Studies by Using Keshary-Chien (K-C) Diffusion Cell. Ex-vivo diffusion study of pure drug was carried out using fresh porcine oral mucosa tissue, placed in Krebs buffer $\mathrm{pH}$ 7.4. Isolation of the epithelium was done mechanically by using scissors and forceps. These studies were carried out using modified $\mathrm{K}-\mathrm{C}$ diffusion cell. A buccal patch was placed over it to secure the patch tightly and prevent it from getting dislodge from the membrane [12].

The donor compartment was filled with $10 \mathrm{~mL}$ of simulated salivary fluid pH 6.8 containing $20 \%$ of methanol. The receptor compartment contained $25 \mathrm{~mL}$ of phosphate buffer pH 7.4 having $20 \%$ methanol to maintain sink conditions. The hydrodynamics in receptor compartment was maintained by stirring with a magnetic bead at $50 \mathrm{rpm}$. The whole assembly was maintained at $37 \pm 2^{\circ} \mathrm{C}$. $1 \mathrm{~mL}$ of samples was withdrawn from receptor compartment at every $1 \mathrm{~h}$ time interval up to $12 \mathrm{~h}$ and replaced with the same amount of fresh medium. The withdrawn samples were then diluted suitably, and analyzed spectrophotometrically at $254 \mathrm{~nm}$, and percentage cumulative drug diffused (Table 4).

Analysis of Release Mechanism. The in-vitro release data were treated by different equations and kinetic models to explain the release kinetics of buspirone hydrochloride from the buccal patches [12].

The kinetic models used were zero order equations and first order equations (Higuchi release, Korsemeyer and Peppas models [13]).

Statistical Optimisation. Statistical experimental designs have been in use for several decades. These experimental layouts can be adopted at various phases of an optimisation process, such as in screening experiments or in finding the optimal conditions for targeted results. The results of statistically planned experiment are better accepted than those of traditional single-variable experiments. Response surface, contour surfaces methodology is now established as a convenient method for developing optimum processes with precise conditions and has minimized the cost of production of many a process with efficient screening of process parameter [1416].

2.2.9. Stability Studies. The purpose of stability testing is to provide evidence on how the quality of a drug substance or drug product varies with time under the influence of a variety of environmental factors such as temperature, humidity, and light, and to establish a retest period for the drug substance or a shelf life for the drug product and recommended storage conditions. To assess the drug and formulation stability, stability studies were done according to ICH guidelines Q1C.

Short-term stability studies were carried out on the films of most satisfactory as per ICH Guidelines Q1C. The most satisfactory formulation stored in sealed in aluminum foil. These were stored at $30 \pm 2^{\circ} \mathrm{C}(65 \pm 5 \% \mathrm{RH})$ and $40 \pm$ $2^{\circ} \mathrm{C}(75 \pm 5 \% \mathrm{RH})$ for 2 months. Films were evaluated for physical characteristics, buccoadhesive properties, in-vitro drug release study and ex-vivo diffusion study.

\section{Results and Discussion}

The sample of buspirone hydrochloride was identified and characterized as per the identification test in official monograph. The physical appearance of drug under investigation found similarity with official monograph. The drug sample complied with results of identification tests as reported in official monograph. The drug purity was identified by Infrared spectroscopy and characteristic peaks were obtained in the spectra for the different functional groups. The solubility profile of drug was determined in aqueous and nonaqueous solvents, buspirone hydrochloride is slightly soluble in ethanol, methanol, freely soluble in phosphate buffer $\mathrm{pH}$ 7.4, and water and soluble in $0.1 \mathrm{~N} \mathrm{HCl}$. The partition coefficient was found to be 2.7 in 1 octanol: PBS ( $\mathrm{pH} \mathrm{6.8).} \mathrm{This} \mathrm{indicated}$ that the drug has an adequate hydrophilic and lipophilic balance.

3.1. Formulation Studies. Buccal films of buspirone hydrochloride were prepared by solvent casting technique. In this design total amount of polymer and percentage of HPMC $\mathrm{K} 15 \mathrm{M}$ were taken as independent variables. Amount of sodium lauryl sulphate and polyethylene glycol 400 were kept constant. Formulations were shown in the Table 2.

\subsection{Evaluation Parameters}

3.2.1. Surface $p H$. An acidic or alkaline formulation is bound to cause irritation on the mucosal membrane and hence this parameter assumes significance while developing a buccoadhesive formulation. Surface $\mathrm{pH}$ of the formulation F1 to F9 was varied from $6.3 \pm 0.02$ to $6.7 \pm 0.05$. Each sample was analyzed in triplicate $(n=3)$. The results were revealed that all the formulations provide an acceptable $\mathrm{pH}$ in the range of 6.2 to 6.8 (salivary $\mathrm{pH}$ ). Hence, they may not produce any local irritation to the mucosa as shown in Table 3. 
TABLE 7: Comparison of various dependent variables of optimized formulations.

\begin{tabular}{lccccccc}
\hline Parameters & $\begin{array}{c}\text { Total Amount of } \\
\text { Polymer }\end{array}$ & $\begin{array}{c}\text { Percentage Of HPMC } \\
\text { K15M }\end{array}$ & $T_{50 \%}(\mathrm{~h})$ & $T_{80 \%}(\mathrm{~h})$ & Diffusion at 3h & Diffusion at 6h Diffusion at 9h \\
\hline Codes & $X_{1}$ & $X_{2}$ & $Y_{1}$ & $Y_{2}$ & $Y_{3}$ & $Y_{4}$ & $Y_{5}$ \\
\hline Desirability & & & 5.25 & 9.28 & 33.18 & 55.60 & 78.01 \\
\hline Predicted OF1 & 400 & 75 & 4.43 & 11.30 & 38.68 & 60.63 & 70.63 \\
Predicted OF2 & 350 & 70 & 4.43 & 11.40 & 39.04 & 60.14 & 70.20 \\
Experimental OF1 & 400 & 75 & 4.12 & 8.56 & $45.56 \pm 1.78$ & $65.78 \pm 2.42$ & $80.42 \pm 2.44$ \\
Experimental OF2 & 350 & 70 & 4.41 & 9.23 & $42.87 \pm 1.54$ & $63.45 \pm 1.84$ & $77.84 \pm 2.20$ \\
\hline
\end{tabular}

3.2.2. Swelling Studies. Any polymer with good swelling property is expected to be a good candidate for bioadhesive application. When bioadhesive is exposed to aqueous medium, they swell and form a gel. The rate and extent of water uptake by a polymer has been reported to be an important factor in determination of its relative bioadhesive strength. Uptake of water results in relaxation of originally stretched, entangled, (or) twisted polymer chain, resulting in exposure of all polymer bioadhesive sites for bonding to occur. The faster this phenomenon occurs the more rapid will be the polymer films adherance to its substrate. The results were revealed that all the formulations provide an acceptable swelling index in the range of 1.09-1.59 as shown in Table 3.

3.2.3. Weight Uniformity. Weight Uniformity of HPMC K15M and Eudragit RL 100 based formulations F1-F9 varied from 146.1 to $456.1 \mathrm{mg}$ as shown in Table 3 .

3.2.4. Thickness. As the total amount of polymer increases the thickness of films were found to be increased. The formulation F7 showed the lowest thickness $(91.74 \pm 0.7 \mu \mathrm{m})$ while formulation F3 showed highest thickness (314.22 \pm $2.6 \mu \mathrm{m})$ as shown in Table 3 .

3.2.5. Folding Endurance. As the amount of HPMC K15M (film forming polymer) increases, the folding endurance was found to be increase. Therefore, formulation F3 showed greater folding endurance $(68 \pm 4)$ compared to other formulations as shown in Table 3.

3.2.6. Drug Content. Drug content for all the formulations was found to be between 98 and 99\%, which within the desirable range as shown in Table 3.

3.2.7. In-Vitro Bioadhesion. As the amount of HPMC K15M increases, the in-vitro bioadhesion was found to be increase. Therefore, formulation F3 showed a greater bioadhesion strength (13.67 $\pm 0.49 \mathrm{~g})$ as shown in Table 3 .

3.2.8. In-Vitro Drug Release Studies. In the formulations, F1 to F3, having HPMC K15M alone, gave faster drug release as compared to other formulations, which had HPMC K15M in combination with Eudragit RL-100, which would retarded

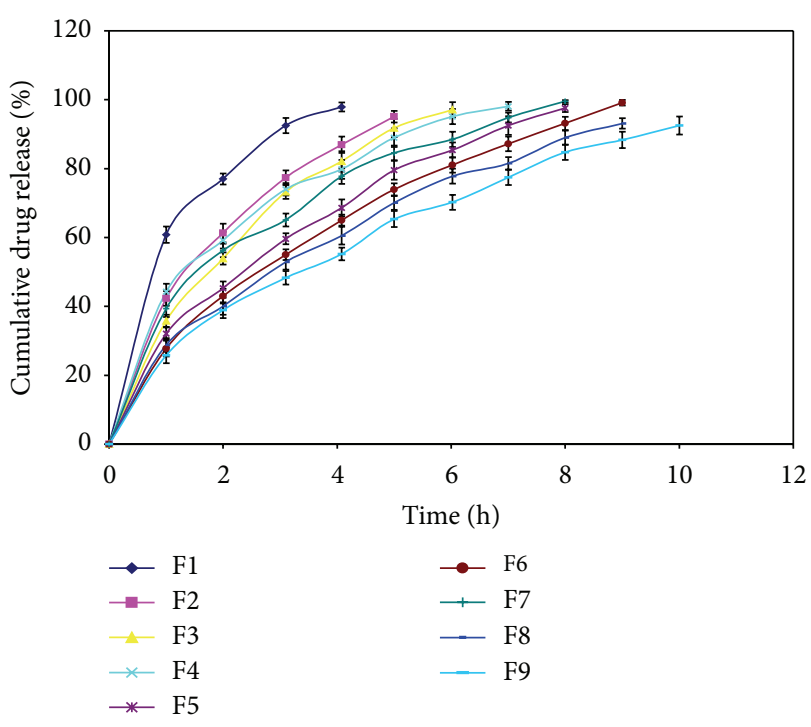

FIGURE 1: In-vitro drug release studies of various formulations.

drug release from the buccal films. Formulation F1 releases 99\% drug within $4 \mathrm{~h}$, while formulation F9 releases $88 \%$ drug within $9 \mathrm{~h}$ as shown in Figure 1.

3.2.9. Ex-Vivo Drug Diffusion Studies. In the formulations, F1 to F3, having HPMC K15M alone, gives faster drug diffusion as compared to other formulations, which had HPMC K15M in combination with Eudragit RL-100, which retarded drug diffusion from the buccal films. Formulation F1 diffuses $99 \%$ drug within $9 \mathrm{~h}$, while formulation F7 diffuses 99\% drug within $12 \mathrm{~h}$ and formulation F9 diffuses $74 \%$ within $12 \mathrm{~h}$ as shown in Figure 2.

3.2.10. Analysis of Release Mechanism. Values of $R^{2}$ were all close to unity, indicating that the first order release behavior is the main release mechanism. Hence release pattern from buccal films are diffusion, in which firstly films were swelled then released slowly as shown in Table 4 .

3.2.11. Fitting of the Data to the Model. A positive value represents an effect that favors the optimization, while the 


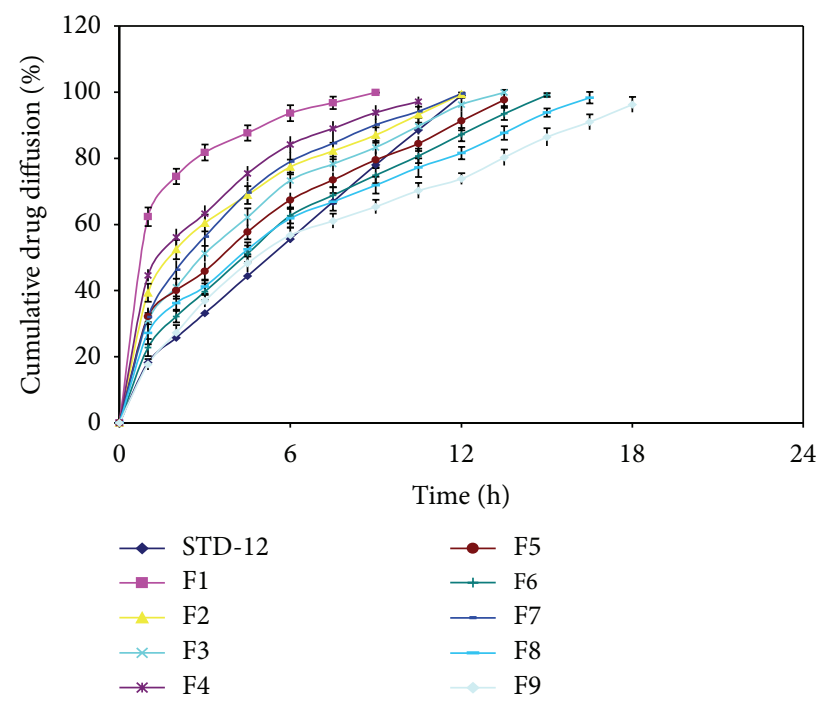

FIGURE 2: Ex-vivo drug diffusion studies of various formulations.

negative value indicates an inverse relationship between factors and responses. It was concluded from the above equation that two variables, that is, total amount of polymer and amount of HPMC K15M, have a greater positive value in equation obtained for $9 \mathrm{~h}$ ex-vivo studies.

Coefficient factor in the regression equation represents interaction between variables. The independent variables change regularly so that factors can reproduce favorable results. Because there are higher positive values of $X_{1}, X_{2}, X_{1} X_{2}, X_{2}^{2}$ obtained in the equation at $9 \mathrm{~h}$ for response surface, this was taken as optimum.

From the fitting of the data to the model, it is clear that data should be selected from $9 \mathrm{~h}$ ex-vivo studies.

3.2.12. Contour Plot and Response Surface Analysis. The two-dimensional and three-dimensional response plots were plotted which were very useful in the study in the interaction effect of the factors on the response. These types of plots useful in the study of the effects of factors on the response at one time. In the entire graph, three variables were kept constant and two variables were changed continuously at different levels so that desired result can be obtained.

The $9 \mathrm{~h}$ ex-vivo studies graph showed optimum responses for the formulation. It was showed linear relationship with statistical calculations as shown in Figures 3, 4, 5, 6, 7, 8, 9, 10, 11 , and 12 .

\subsubsection{Optimisation}

$T_{50 \%}$. One has

$$
\begin{aligned}
Y= & 0.2641145 * X_{1}-0.0135311 * X_{2}-0.0005793 * X_{1} X_{2} \\
& -0.002202 * X_{1}^{2}-0.0003349 * X_{2}^{2} .
\end{aligned}
$$

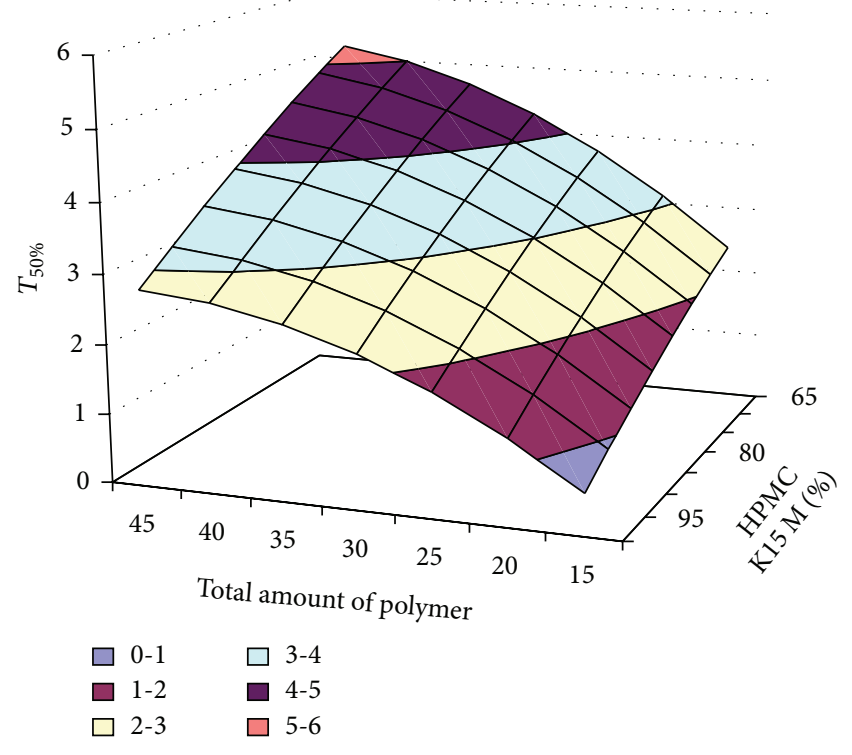

FIgURE 3: Surface plot of $T_{50 \%}$ for the optimization of amount of HPMC K15M and total amount of polymer.

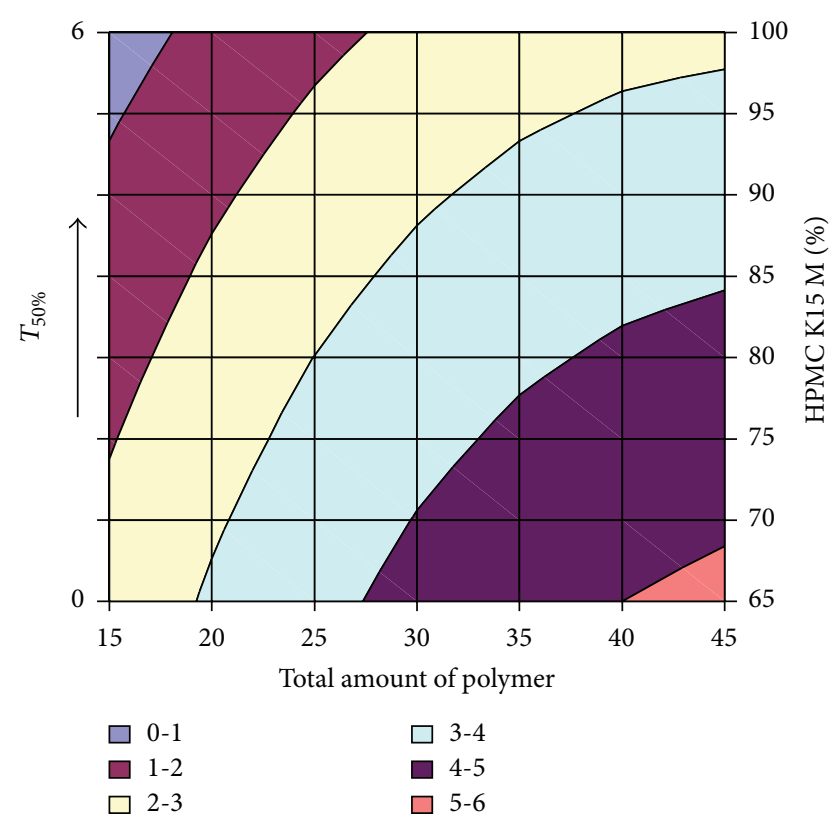

FIgURE 4: Contour plot of $T_{50 \%}$ for the optimization of amount of HPMC K15M and total amount of polymer.

$T_{80 \%}$. One has

$$
\begin{aligned}
Y= & 0.6412898 * X_{1}-0.0447662 * X_{2}-0.0003357 * X_{1} X_{2} \\
& -0.0070657 * X_{1}^{2}-0.000959 * X_{2}^{2} .
\end{aligned}
$$




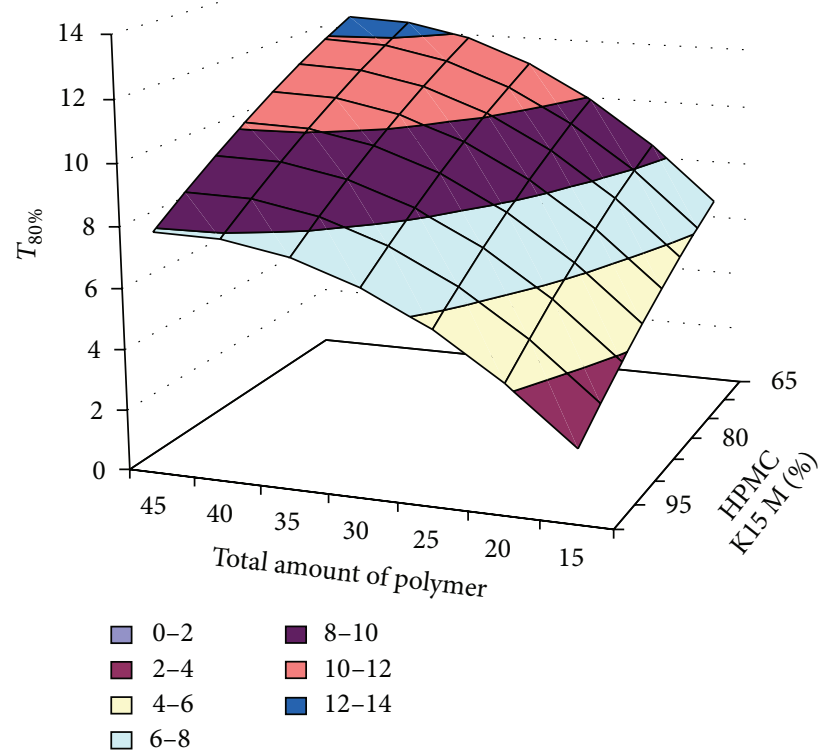

Figure 5: Surface plot of $T_{80 \%}$ for the optimization of amount of HPMC K15M and total amount of polymer.

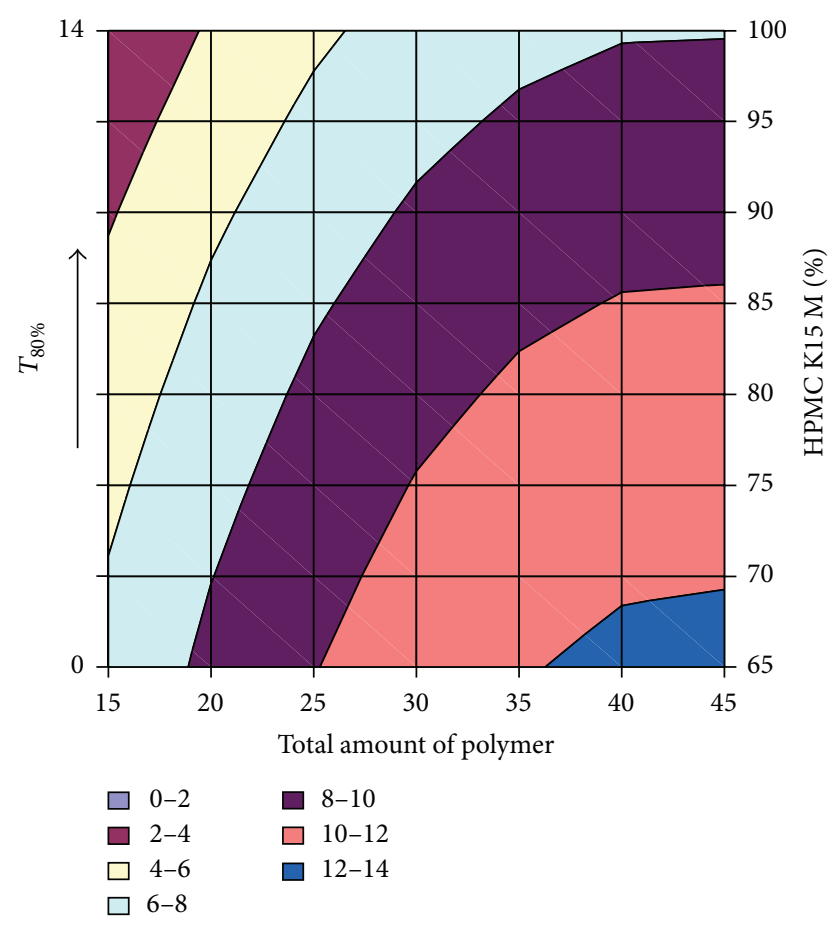

Figure 6: Contour plot of $T_{80 \%}$ for the optimization of amount of HPMC K15M and total amount of polymer.

$3 h$. One has

$$
\begin{aligned}
Y= & 97.50941-1.41006 * X_{1}+0.98072 * X_{2}-0.0112013 \\
& * X_{1} X_{2}+0.0252299 * X_{1}^{2}+0.0114420 * X_{2}^{2} .
\end{aligned}
$$

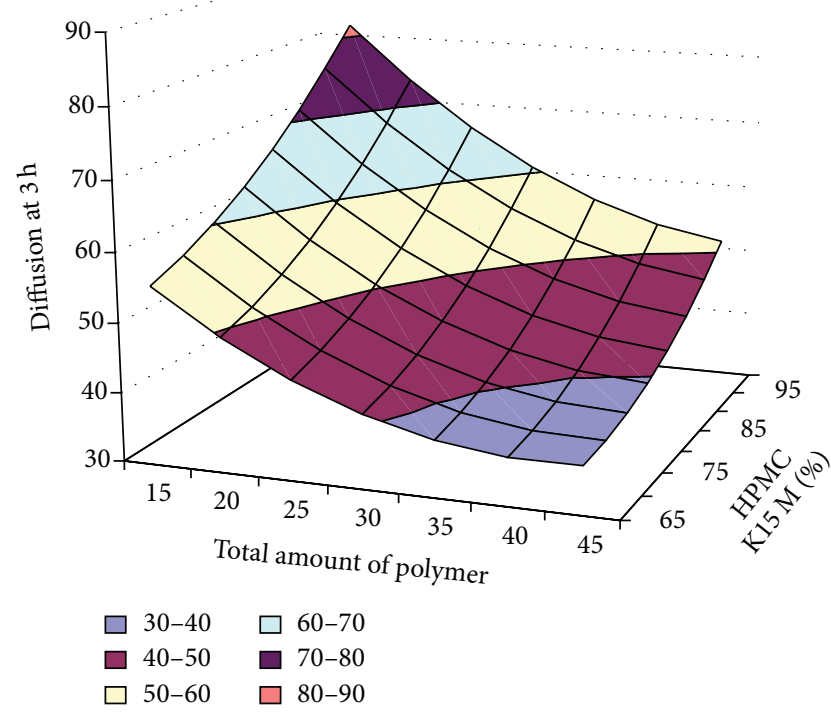

FIgURE 7: Surface plot diffusion at $3 \mathrm{~h}$ for the optimization total amount of polymer and HPMC K15M.

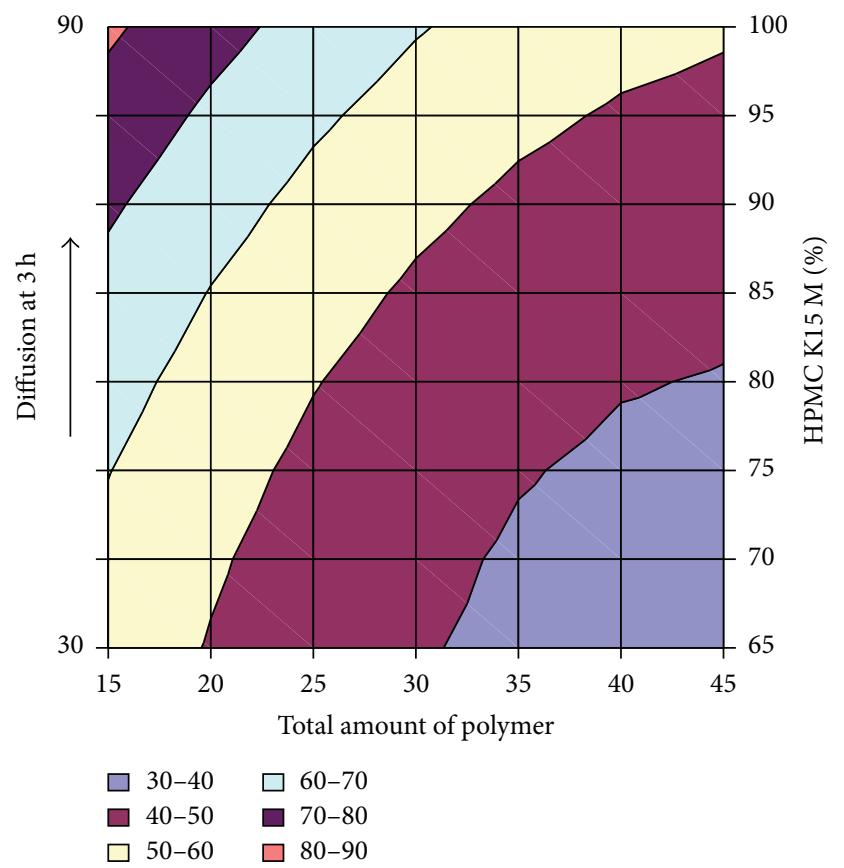

FIgURE 8: Contour plot of diffusion at $3 \mathrm{~h}$ for the optimization total amount of polymer and HPMC K15M.

$6 \mathrm{~h}$. One has

$$
\begin{aligned}
Y= & 97.967623+2.4813106 * X_{1}+0.0150901 * X_{2} \\
& +0.0019077 * X_{1} X_{2}+0.026712 * X_{1}^{2} \\
& +0.0025469 * X_{2}^{2} .
\end{aligned}
$$




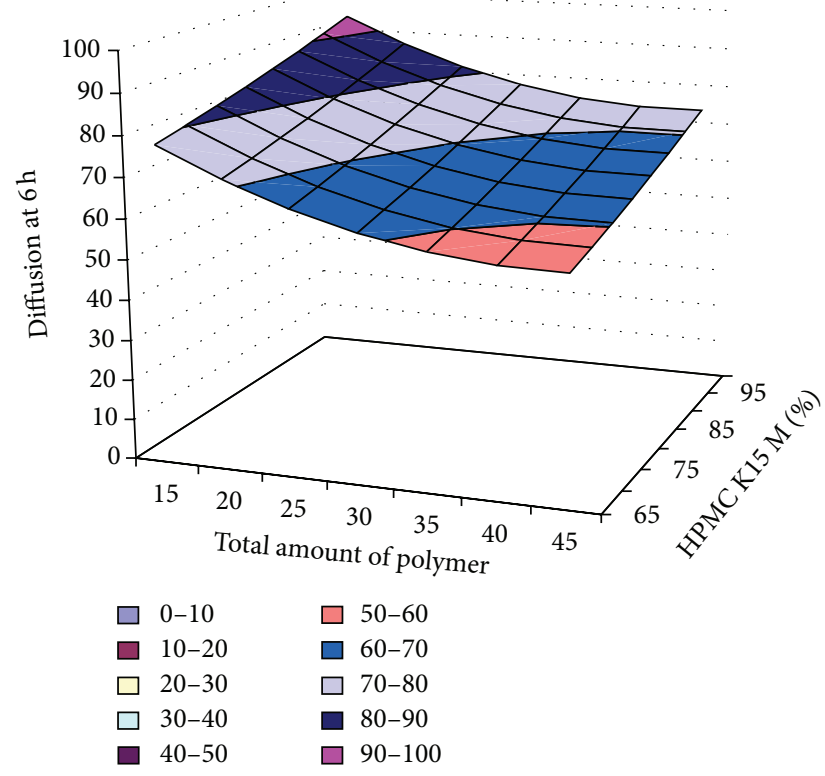

FIgURE 9: Surface plot of diffusion at $6 \mathrm{~h}$ for the optimization total amount of polymer and HPMC K15M.

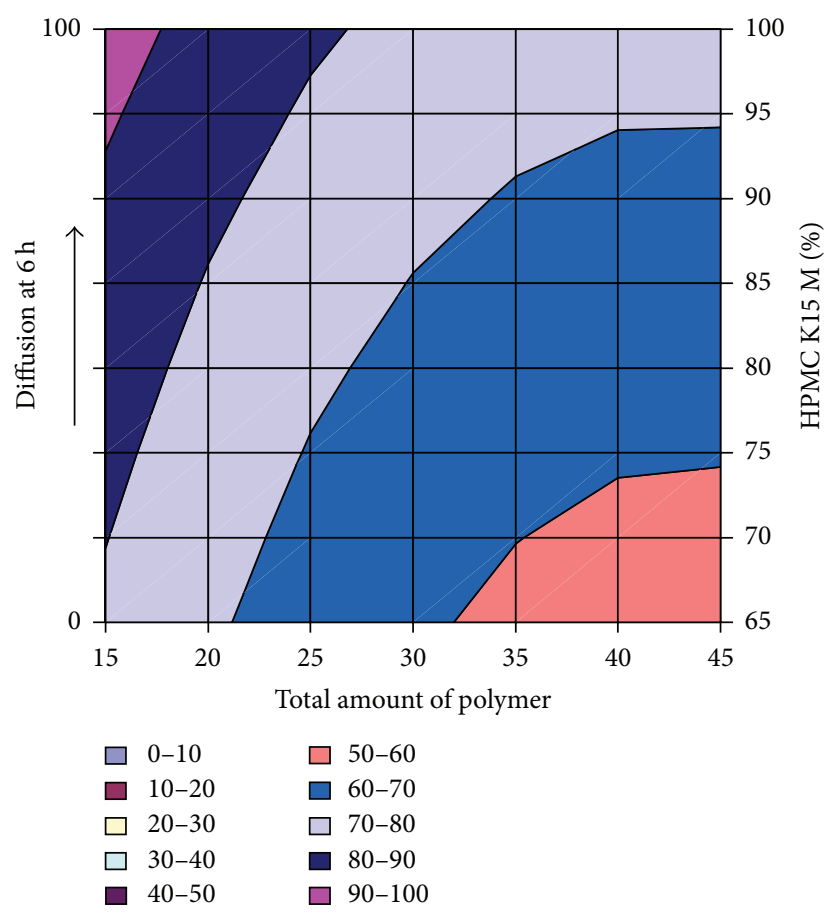

FIGURE 10: Contour plot of diffusion at $6 \mathrm{~h}$ for the optimization total amount of polymer and HPMC K15M.

$9 h$. One has

$$
\begin{aligned}
Y= & 97.996144-2.424963 * X_{1}+0.2108694 * X_{2} \\
& +0.0059851 * X_{1} X_{2}+0.0212542 * X_{1}^{2} \\
& +0.0003545 * X_{2}^{2} .
\end{aligned}
$$

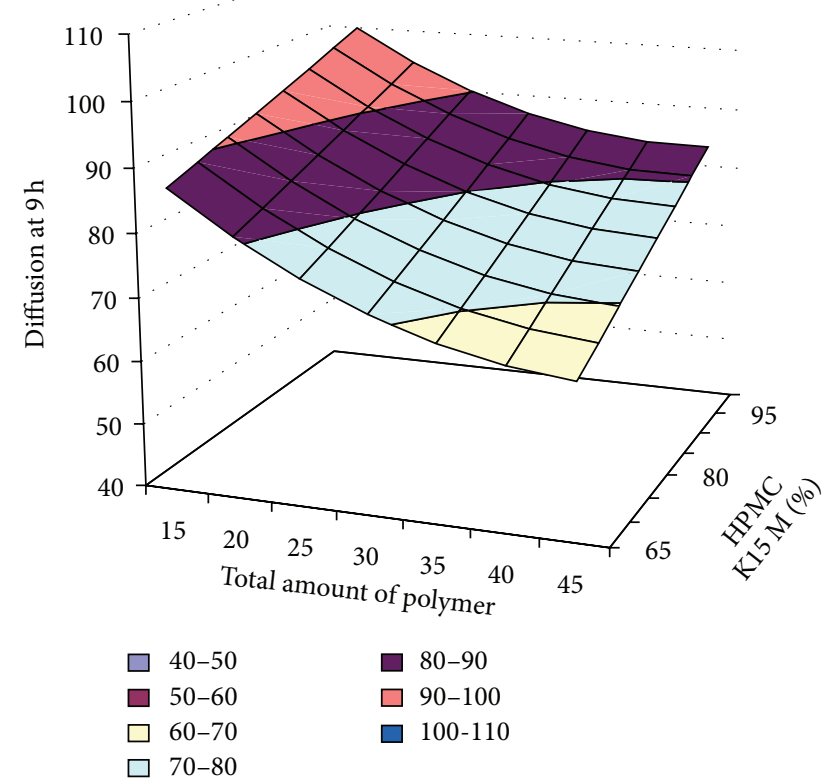

FIGURE 11: Surface plot of diffusion at $9 \mathrm{~h}$ for the optimization total amount of polymer and HPMC K15M.

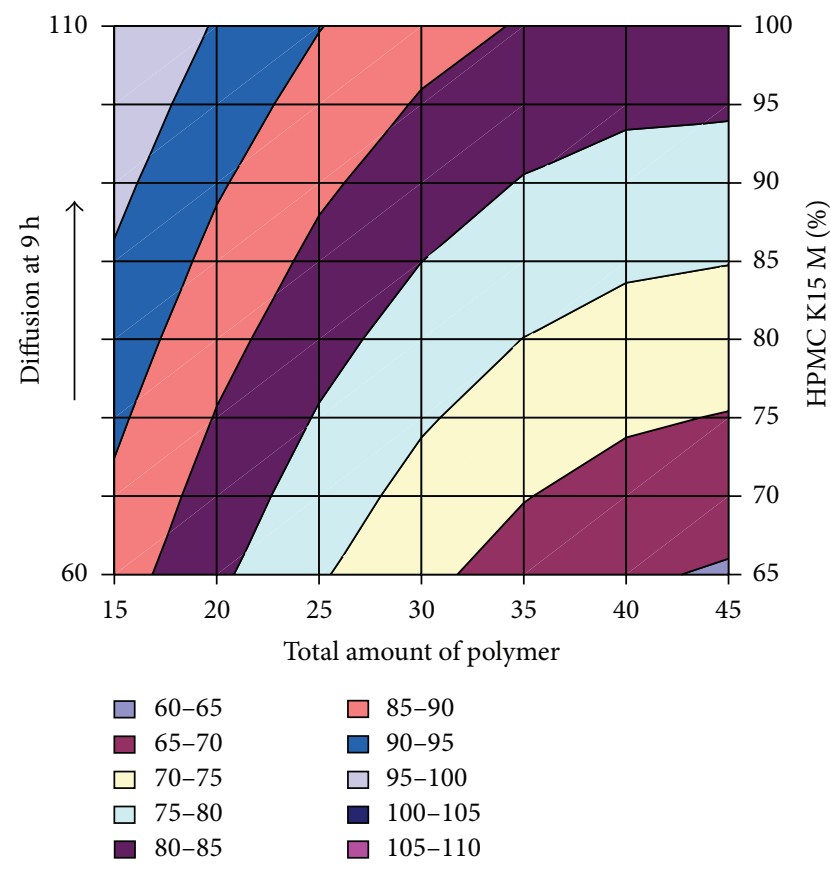

FIgURE 12: Contour plot of diffusion at $9 \mathrm{~h}$ for the optimization total amount of polymer and HPMC K15M.

3.2.14. Optimisation. The optimum formula was selected, based on ex-vivo studies. Upon trading of various response variables and comprehensive evaluation of feasibility search, the formulation composition with total amount of polymer was $400 \mathrm{mg}, 350 \mathrm{mg}$, and for HPMC $\mathrm{K} 15 \mathrm{M}$ is $75 \% \mathrm{w} / \mathrm{w}$, $70 \% \mathrm{w} / \mathrm{w}$ for both optimized batches respectively. These 


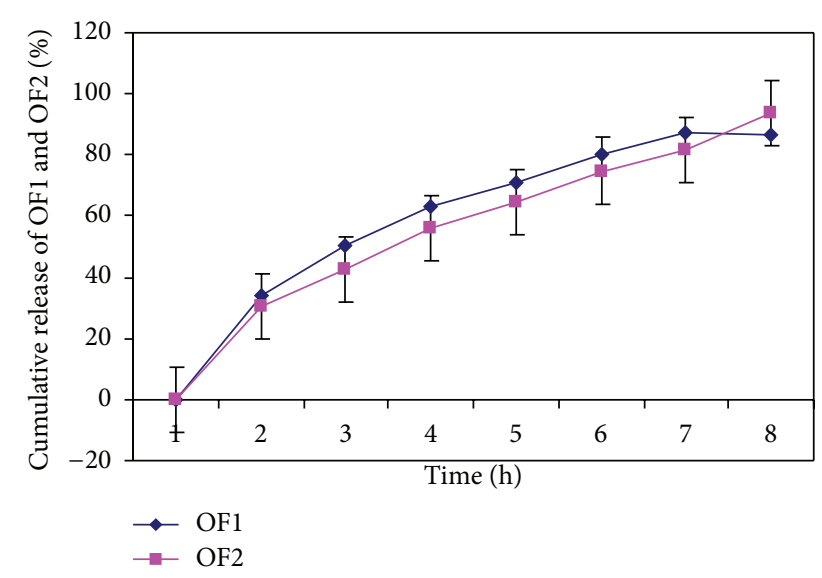

FIGURE 13: In-vitro drug release profile of optimized formulation $\mathrm{OF} 1$ and OF2.

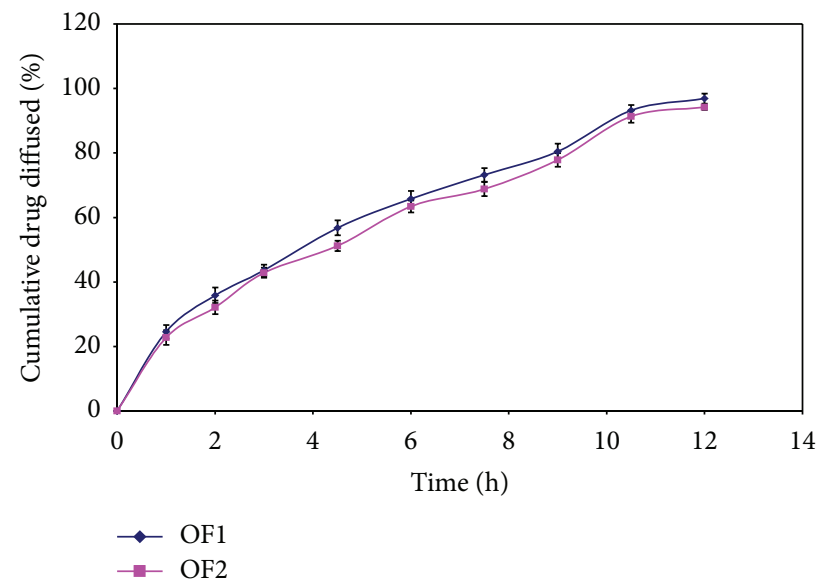

FIGURE 14: Ex-vivo drug diffusion profile of optimized formulations $\mathrm{OF} 1$ and $\mathrm{OF} 2$.

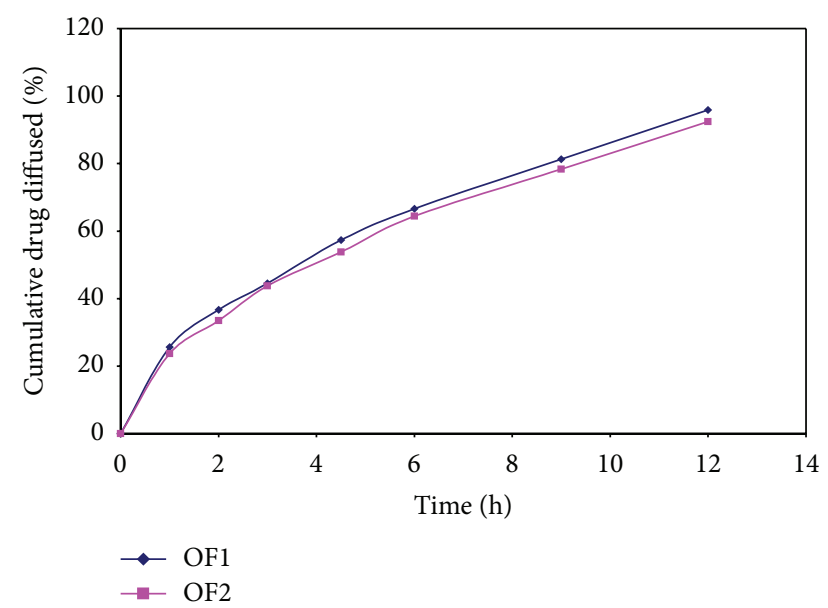

FIGURE 15: Plot of ex-vivo diffusion profile of optimized formulations at $30^{\circ} \mathrm{C} \pm 2^{\circ} \mathrm{C}(65 \% \pm 5 \% \mathrm{RH})$ after 60 days.

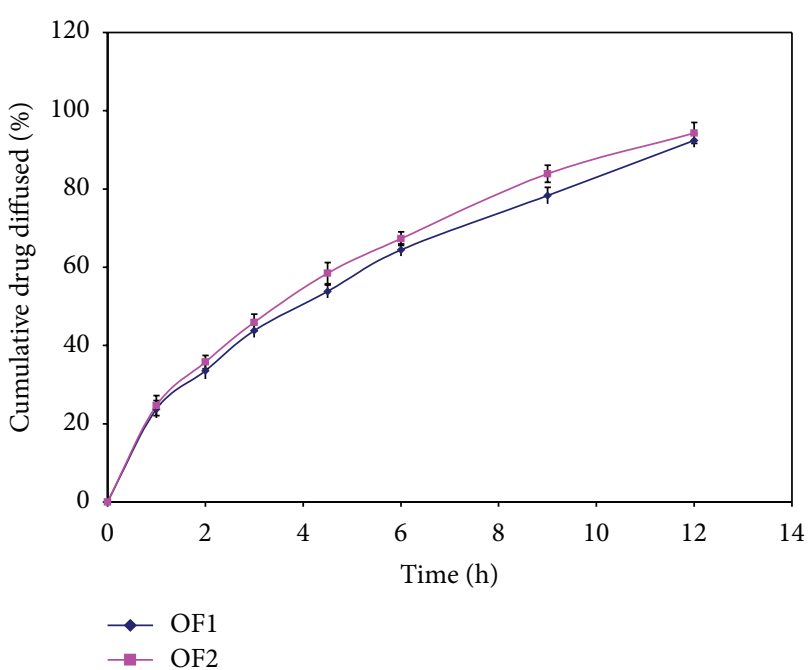

FIgURE 16: Plot of ex-vivo diffusion profile of optimized formulations at $40^{\circ} \mathrm{C} \pm 2^{\circ} \mathrm{C}(75 \% \pm 5 \% \mathrm{RH})$ after 60 days.

were found to fulfill the maximum requisites for optimum formulation.

Hence, optimized formula was prepared by optimum amount of HPMC K15M and Eudragit RL-100, as per value obtained above as shown in Table 5 .

\subsection{Evaluation of Optimized Formulation}

3.3.1. Surface $p H$. Surface $\mathrm{pH}$ of the optimized formulation $\mathrm{OF} 1$ and OF2 displayed a $\mathrm{pH}$ of $6.2 \pm 0.03$ and $6.4 \pm 0.04$, respectively, which was within desirable range as shown in Table 6.

3.3.2. Swelling Studies. The results revealed that optimized formulations provided an acceptable swelling index in the range of 1.17-1.21 as shown in Table 6.

3.3.3. Weight Uniformity. Weight uniformity of HPMC K15M and Eudragit RL-100 based optimized formulations OF1 and OF2 showed $(413.21 \pm 2.66) \mathrm{mg}$ and $(353.47 \pm 3.48) \mathrm{mg}$, respectively, as shown in Table 6.

3.3.4. Thickness. Thickness of optimized formulations OF1 and OF2 was $292.52 \pm 1.65 \mu \mathrm{m}$ and $259.69 \pm 2.23 \mu \mathrm{m}$, respectively, as shown in Table 6 .

3.3.5. Folding Endurance. Folding endurance of optimized formulation OF1 and OF2 was $144 \pm 3$ and $138 \pm 4$, which are within desirable range as shown in Table 6 .

3.3.6. Drug Content. Drug content of optimized formulations was found to be between 98 and $99 \%$, which was within the desirable range as shown in Table 6.

3.3.7. In-Vitro Bioadhesion. In-vitro Bioadhesion of optimized formulation OF1 and OF2 was found to be between 


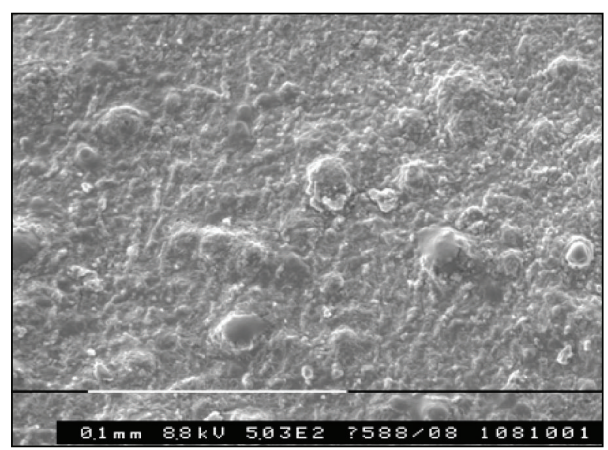

Before drug release

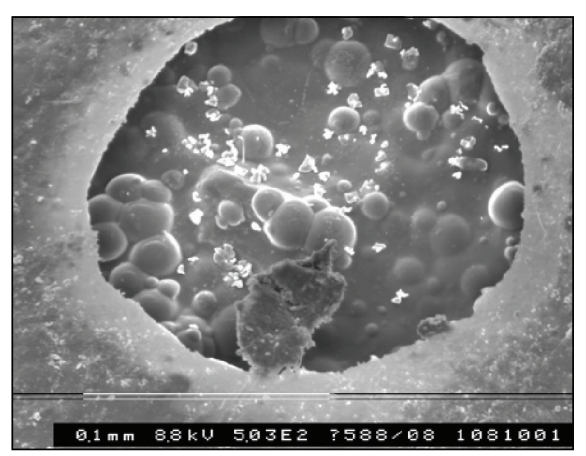

After drug release

FIGURE 17: Scanning electron micrographs of surfaces of drug-containing buccal films of OF2 formulation.

TABLE 8: Physicochemical properties of optimized formulations during the stability studies.

\begin{tabular}{|c|c|c|c|c|c|c|c|}
\hline \multirow{2}{*}{\multicolumn{2}{|c|}{$\begin{array}{c}\text { Formulation code } \\
\text { Time (Days) }\end{array}$}} & \multicolumn{3}{|c|}{ OF1 } & \multicolumn{3}{|c|}{ OF2 } \\
\hline & & 0 & 30 & 60 & 0 & 30 & 60 \\
\hline \multirow{2}{*}{ Surface $\mathrm{pH}$} & A & $6.1 \pm 0.02$ & $6.1 \pm 0.03$ & $6.2 \pm 0.04$ & $6.3 \pm 0.04$ & $6.4 \pm 0.05$ & $6.4 \pm 0.07$ \\
\hline & $\mathrm{B}$ & $6.1 \pm 0.04$ & $6.2 \pm 0.03$ & $6.3 \pm 0.05$ & $6.3 \pm 0.04$ & $6.4 \pm 0.03$ & $6.4 \pm 0.07$ \\
\hline \multirow{2}{*}{ Swelling studies } & A & 1.18 & 1.18 & 1.17 & 1.13 & 1.12 & 1.12 \\
\hline & $\mathrm{B}$ & 1.18 & 1.17 & 1.17 & 1.13 & 1.11 & 1.08 \\
\hline \multirow{2}{*}{ Weight uniformity } & A & $435.70 \pm 1.59$ & $426.79 \pm 2.28$ & $423.54 \pm 2.65$ & $384.39 \pm 2.38$ & $378.47 \pm 3.32$ & $375.76 \pm 2.29$ \\
\hline & B & $435.70 \pm 1.59$ & $423.86 \pm 2.18$ & $421.65 \pm 2.58$ & $384.39 \pm 2.38$ & $372.71 \pm 1.63$ & $370.34 \pm 2.34$ \\
\hline \multirow{2}{*}{ Thickness $(\mu \mathrm{m})^{*}$} & A & $283.35 \pm 1.54$ & $282.45 \pm 1.65$ & $282.13 \pm 1.87$ & $251.56 \pm 1.97$ & $249.31 \pm 2.12$ & $249.06 \pm 2.33$ \\
\hline & B & $283.35 \pm 1.54$ & $280.76 \pm 1.32$ & $280.45 \pm 1.21$ & $251.56 \pm 1.97$ & $247.12 \pm 3.34$ & $246.41 \pm 3.12$ \\
\hline \multirow{2}{*}{ Folding endurance ${ }^{*}$} & A & $134 \pm 2$ & $131 \pm 3$ & $129 \pm 4$ & $126 \pm 3$ & $122 \pm 4$ & $121 \pm 5$ \\
\hline & $\mathrm{B}$ & $134 \pm 2$ & $130 \pm 4$ & $128 \pm 4$ & $126 \pm 3$ & $121 \pm 3$ & $119 \pm 5$ \\
\hline \multirow{2}{*}{ Drug content ${ }^{*}$} & A & $96.21 \pm 2.47$ & $95.17 \pm 3.12$ & $93.28 \pm 2.27$ & $95.53 \pm 1.96$ & $93.29 \pm 2.78$ & $91.18 \pm 2.65$ \\
\hline & $\mathrm{B}$ & $96.21 \pm 2.47$ & $93.34 \pm 2.19$ & $92.19 \pm 2.43$ & $95.53 \pm 1.96$ & $92.67 \pm 2.79$ & $90.29 \pm 2.52$ \\
\hline
\end{tabular}

A: $30^{\circ} \mathrm{C} \pm 2^{\circ} \mathrm{C} / 65 \% \pm 5 \% \mathrm{RH} ; \mathrm{B}: 40^{\circ} \mathrm{C} \pm 2^{\circ} \mathrm{C} / 75 \% \pm 5 \% \mathrm{RH}$.

${ }^{*}$ Data represents mean $\pm \mathrm{SD}, n=3$.

9 and $10 \mathrm{~g}$, which is within the desirable range as shown in Table 6.

3.3.8. In-Vitro Drug Release Studies. Optimized formulations OF1 and OF2 release 98\% drug within $6 \mathrm{~h}$ and $9 \mathrm{~h}$, respectively, as shown in Figure 13.

3.3.9. Ex-Vivo Drug Diffusion Studies. Optimized formulations OF1 and OF2 diffuse drug $96.87 \pm 1.55 \%$ and $94.16 \pm$ 2.13\%, respectively, as shown in Figure 14.

3.3.10. Statistical Analysis-Comparison of Various Variables. It showed that experimental values of $T_{50 \%}$ and $T_{80 \%}$, diffusion at $3 \mathrm{~h}$, diffusion at $6 \mathrm{~h}$, and diffusion at $9 \mathrm{~h}$. OF1 and OF2 were near to expected values of OF1 and OF2, respectively, and also significant by similar desirable data as shown in Table 7.

3.3.11. Stability Studies. From the stability studies, it was concluded that no significant changes were found in the physicochemical parameters, ex-vivo drug diffusion profile of both optimized formulation after stability studies is shown in Tables 8 and 9 and in Figures 15 and 16.

3.3.12. Scanning Electron Microscopy. Surface topography of buccal films was carried out. SEM study showed that erosion was found on the surface of buccal films, which indicates that drug was released by diffusion mechanism as shown in Figure 17.

\section{Conclusion}

In the present study, an attempt was made to design buccal films of buspirone Hydrochloride for treatment/management of anxiety. The main interest in such a dosage form was to formulate buccal films of buspirone Hydrochloride in order to increase bioavailability by avoiding first-pass metabolism and to control drug release in therapeutic range for longer period. Buccal films of buspirone hydrochloride were prepared by solvent casting technique using $3^{2}$ full factorial designs. In this dosage form, hydrophilic water-soluble film forming polymer HPMC K15M and hydrophobic water permeable polymer (Eudragit RL-100) for controlling the diffusion of 
TABLE 9: In-vitro bioadhesive strength of optimized formulations.

\begin{tabular}{llc}
\hline Formulations & \multicolumn{2}{c}{ Bioadhesion strength $^{*}(\mathrm{~g})$} \\
\hline \multirow{2}{*}{ OF1 } & A & $8.85 \pm 1.56$ \\
& B & $8.18 \pm 1.27$ \\
\hline \multirow{2}{*}{ OF2 } & A & $8.27 \pm 1.29$ \\
& B & $7.85 \pm 1.17$ \\
\hline
\end{tabular}

$\mathrm{A}: 30^{\circ} \mathrm{C} \pm 2^{\circ} \mathrm{C}(65 \% \pm 5 \% \mathrm{RH}) ; \mathrm{B}: 40^{\circ} \mathrm{C} \pm 2^{\circ} \mathrm{C}(75 \% \pm 5 \% \mathrm{RH})$.

${ }^{*}$ Data represents mean $\pm \mathrm{SD}, n=3$.

drug. Optimisation of various parameters like $T_{50 \%}$ and $T_{80 \%}$ and diffusion at $3 \mathrm{~h}, 6 \mathrm{~h}$, and $9 \mathrm{~h}$ were carried out and optimized formulations were developed. Results of optimized formulations $\mathrm{OF} 1$ and $\mathrm{OF} 2$ closely met targeted data and continuously diffused drug for $12 \mathrm{~h}$, which can maintain desired therapeutic concentration in plasma. Stability study of optimized formulations OF1 and OF2 was performed which showed slight change in physicochemical parameters and drug diffusion profile.

Hence, from the above all discussion it is concluded that OF1 and OF2 formulation proved to be the best formulations, which have increased bioavailability and prolonged release time.

\section{Conflict of Interests}

The authors declare that there is no conflict of interests regarding the publication of this paper.

\section{Acknowledgments}

The authors are thankful to Sun Pharmaceuticals, Ahmedabad, for providing the gift sample of Eudragit RL-100. The authors are also thankful to the Honorable Founder President, Amity University, Uttar Pradesh, and worthy ViceChancellor, Amity University, Noida, for providing necessary facilities to carry out this research work.

\section{References}

[1] M. Alagusundaram, C. Chetty, and D. Dhachinamoorthi, "Development and evaluation of novel-trans-buccoadhesive films of famotidine," Journal of Advanced Pharmaceutical Technology and Research, vol. 2, no. 1, pp. 17-23, 2011.

[2] J. C. Ballenger, J. R. T. Davidson, Y. Lecrubier, and D. J. Nutt, "A proposed algorithm for improved recognition and treatment of the depression/anxiety spectrum in primary care," Primary Care Companion to the Journal of Clinical Psychiatry, vol. 3, no. 2, pp. 44-52, 2001.

[3] S. Burgalassi, L. Panichi, M. F. Saettone, J. Jacobsen, and M. R. Rassing, "Development and in vitro/in vivo testing of mucoadhesive buccal patches releasing benzydamine and lidocaine," International Journal of Pharmaceutics, vol. 133, no. 1-2, pp. 17, 1996.

[4] D. Harris and J. R. Robinson, "Drug delivery via the mucous membranes of the oral cavity," Journal of Pharmaceutical Sciences, vol. 81, no. 1, pp. 1-10, 1992.

[5] R. C. Doijad, F. V. Manvi, V. S. N. Malleswara Rao, and P. S. Patel, "Buccoadhesive drug delivery system of isosorbide dinitrate: formulation and evaluation," Indian Journal of Pharmaceutical Sciences, vol. 68, no. 6, pp. 744-748, 2006.

[6] K. G. H. Desai and T. M. Pramod Kumar, "Preparation and evaluation of a novel buccal adhesive system," AAPS PharmSciTech, vol. 5, no. 3, pp. 1-9, 2004.

[7] B. M. Boddupalli, Z. N. K. Mohammed, A. R. Nath, and D. Banji, "Mucoadhesive drug delivery system: an overview," Journal of Advanced Pharmaceutical Technology and Research, vol. 1, no. 4, pp. 381-387, 2010.

[8] A. J. Hoogstraate, J. C. Verhoef, B. Tuk et al., "In-vivo buccal delivery of fluorescein isothiocyanate-dextran 4400 with glycodeoxycholate as an absorption enhancer in pigs," Journal of Pharmaceutical Sciences, vol. 85, no. 5, pp. 457-460, 1996.

[9] R. Ilango, S. Kavimani, A. R. Mullaicharam, and B. Jayakar, "Invitro studies on buccal strips of glibenclamide using chitosan," Indian Journal of Pharmaceutical Sciences, vol. 59, no. 5, pp. 232 235, 1997.

[10] R. Khanna, S. P. Agarwal, and A. Ahuja, "Preparation and evaluation of muco-adhesive buccal films of clotrimazole for oral Candida infections," Indian Journal of Pharmaceutical Sciences, vol. 59, no. 6, pp. 299-305, 1997.

[11] R. K. Khar, F. J. Ahmad, U. Ubaidulla, M. V. S. Reddy, and K. Ruckmani, "Transdermal therapeutic system of carvedilol: effect of hydrophilic and hydrophobic matrix on in vitro and in vivo characteristics," AAPS PharmSciTech, vol. 8, no. 1, pp. 2-10, 2007.

[12] C. Sánchez-Lafuente, M. Teresa Faucci, M. Fernández-Arévalo, J. Álvarez-Fuentes, A. M. Rabasco, and P. Mura, "Development of sustained release matrix tablets of didanosine containing methacrylic and ethylcellulose polymers," International Journal of Pharmaceutics, vol. 234, no. 1-2, pp. 213-221, 2002.

[13] Y. Vamshi Vishnu, K. Chandrasekhar, G. Ramesh, and Y. Madhusudan Rao, "Development of mucoadhesive patches for buccal administration of carvedilol," Current Drug Delivery, vol. 4, no. 1, pp. 27-39, 2007.

[14] M. Sheikhzadeh, S. Rohani, M. Taffish, and S. Murad, "Solubility analysis of buspirone hydrochloride polymorphs: measurements and prediction," International Journal of Pharmaceutics, vol. 338, no. 1-2, pp. 55-63, 2007.

[15] A. H. Shojaei, "Buccal mucosa as a route for systemic drug delivery: a review," Journal of Pharmacy \& Pharmaceutical Sciences, vol. 1, no. 1, pp. 15-30, 1998.

[16] U. Nagaich, V. Chaudhary, and R. Karki, Formulation and Evaluation of Buspirone Hydrochloride Buccal Films, Lap Lambert Academic Publishing, 2011. 

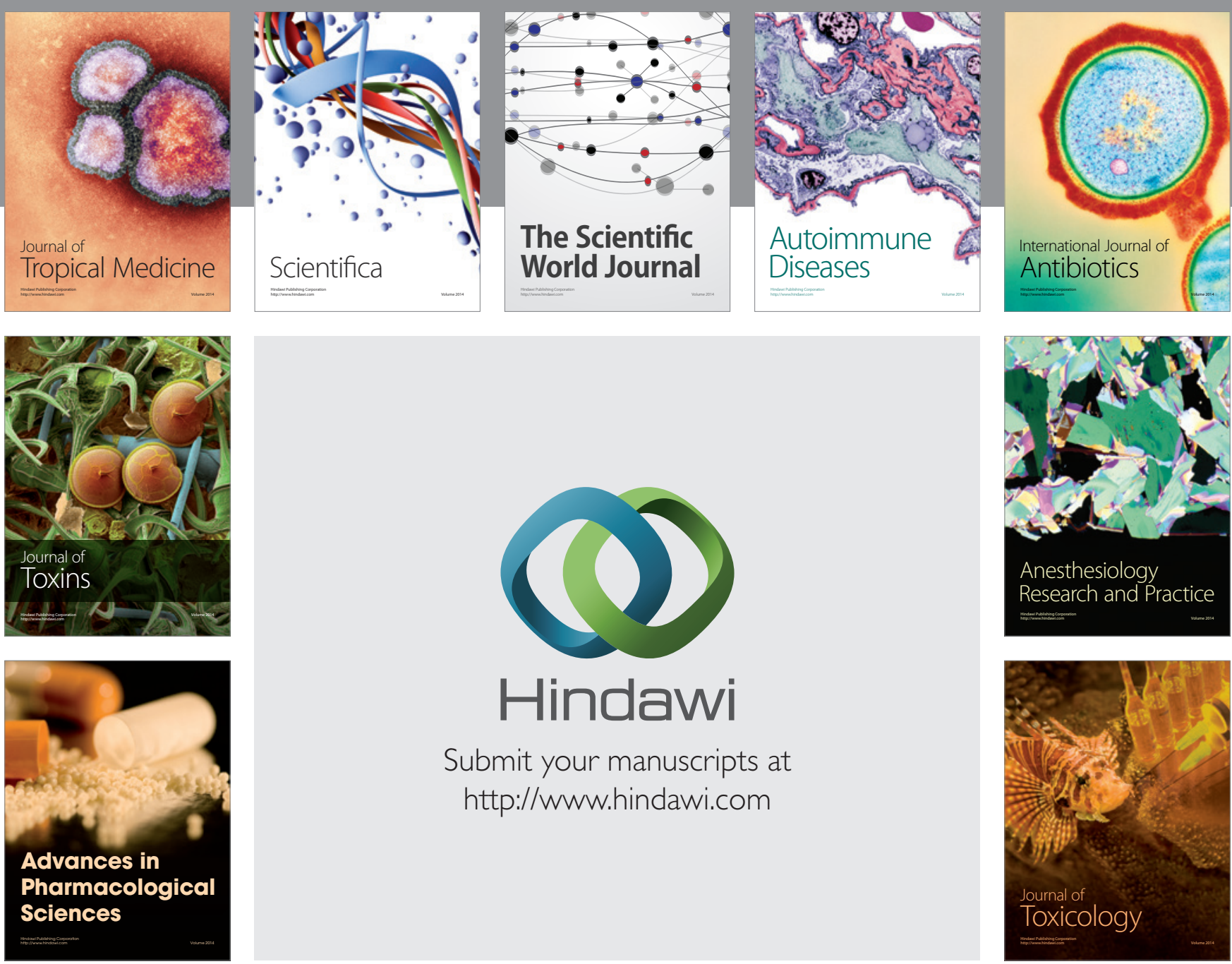

\section{Hindawi}

Submit your manuscripts at

http://www.hindawi.com
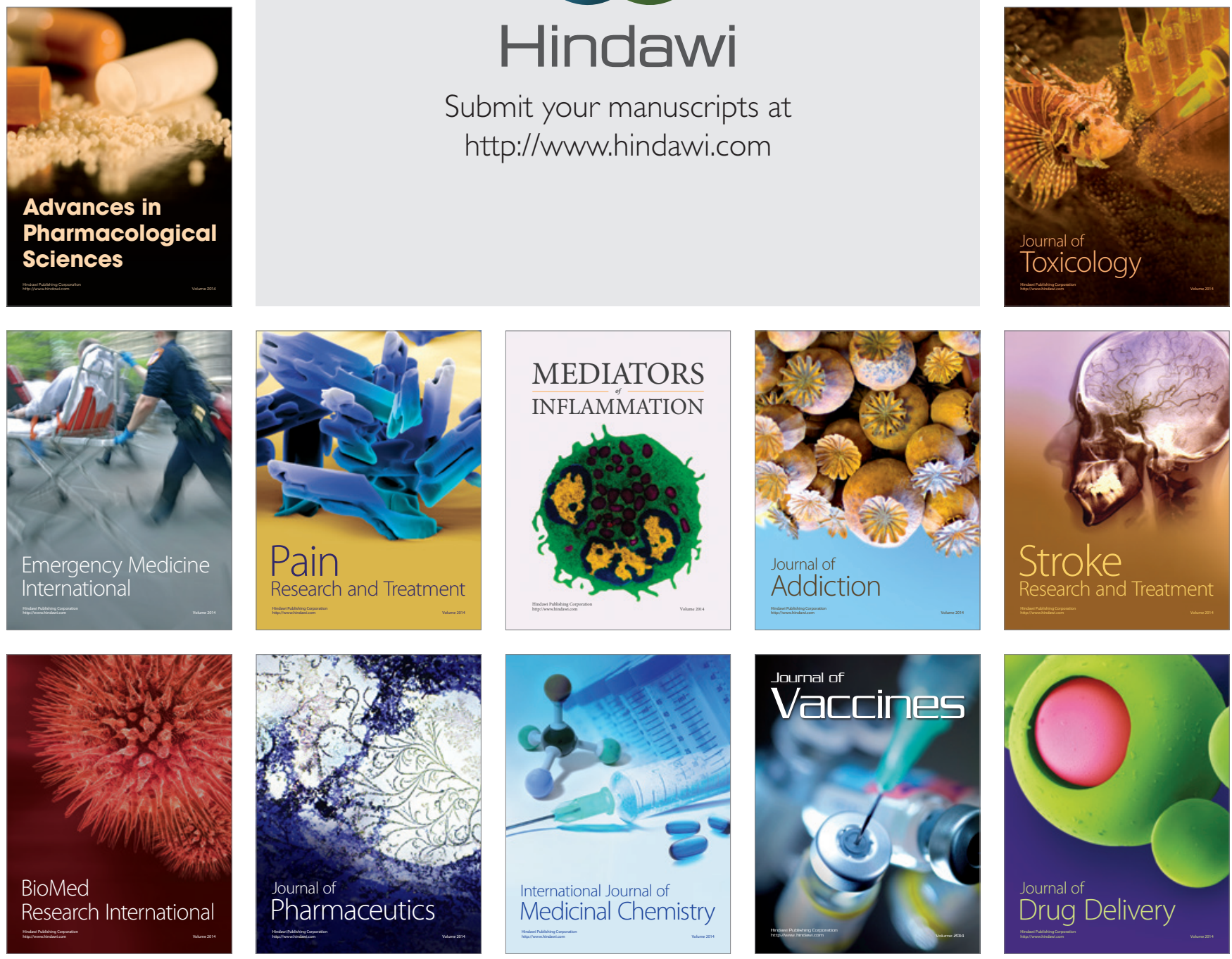